\section{Colony Production in vitro by Normal Polycythaemic and Anaemic Bone Marrow}

THe growth of colonies from mouse bone marrow cells in solid agar medium in vitro has been described recently ${ }^{1}$. The colony growth required stimulation by feeder layer cells, the most effective of which were neonatal mouse kidney cells. Although the colonies appear to arise by the proliferation of single cells, the colony cell population is a mixture of myeloid cells and mononuclear cells and the identity of the cells responsible for the initiation of colony formation has not been established. In order to gain more information on the in vitro colony forming cells the following studies have been made comparing the numbers of colony forming cells in normal, polycythaemic and anaemic mouse bone marrows.

Male mice strain $C 57 B L 3$ months old were used throughout. They were rendered polycythaemic by daily intraperitoneal injection of $0.5 \mathrm{ml}$. packed isologous red cells (triple washed in normal saline). Injections of cells were made for 4 consecutive days. Anaemic mice were produced by bleeding $0.3 \mathrm{ml}$. of blood daily from the tail vessels for 4 consecutive days. The marrows of groups of four normal, polycythaemic and anaemic mice were pooled and tested simultaneously for colony forming ability on the fifth day.

The technique used for the bone marrow culture has been described in detail elsewhere ${ }^{1}$. In brief, nonirradiated feeder layers of trypsinized kidney cells from 8 day old $C 57 B L$ mice were prepared by the addition of the cells, suspended in Eagle's minimal essential medium (supplemented with serum (10 per cent) and trypticase soy broth (10 per cent)), to an equal volume of I per cent agar solution. Aliquots of the cell suspension in agar of $5 \mathrm{ml}$, containing $5 \times 10^{6}$ kidney cells, were plated in $60 \mathrm{~mm}$ glass Petri dishes and allowed to gel.

Nucleated cell counts were made on the pooled marrow single cell suspensions and media containing 15,625; 62,$500 ; 250,000$ and $1 \times 10^{6}$ cells $/ \mathrm{ml}$. of each of the three pools were prepared, mixed with an equal volume of 0.6 per cent agar solution and $2 \mathrm{ml}$. aliquots plated on top of the previously prepared feeder layers. Control dishes were prepared identically except that the feeder layer cells were omitted. After the upper layers containing the target bone marrow cells were allowed to gel, the dishes were incubated at $37^{\circ} \mathrm{C}$ for 10 days in a humidified incubator gassed with 5 per cent carbon dioxide in air. Colony counts were made using a dissecting microscope. Three separate experiments were made, which were identical except for a change in serum used in the medium in the second and third experiments.

The results are listed in Table 1. Control dishes without feeder kidney cells yielded no colonies with marrow cells from each of the three treatment groups. A linear increase in colonies formed was obtained with increasing numbers of bone marrow cells from all three groups of mice. With the marrow cells from the polycythaemic mice, however, significantly larger numbers of colonies were

Table 1. NUMBER OF COLONIES FORMED in vitro BX CELLS FROM VARIOUS Table 1. NUMBER OF COLONIES FORMED in vitro BX

$\begin{array}{crc}\begin{array}{c}\text { Type of } \\ \text { donor } \\ \text { bone } \\ \text { marrow }\end{array} & \begin{array}{c}\text { Experi- } \\ \text { ment } \\ \text { No. }\end{array} & \begin{array}{c}\text { Mean haema- } \\ \text { tonor mit of } \\ \text { (per cent) }\end{array} \\ \text { Normal } & \text { I } & 48 \\ & \text { II } & 47 \\ \text { III } & 48 \\ \text { Poly- } & \text { I } & 80 \\ \text { cythaemic } & \text { II } & 76 \\ & \text { III } & 77 \\ \text { Anaemic } & \text { II } & 21 \\ & \text { II } & 24 \\ & \text { III } & 23\end{array}$

No. of colonies formed by various numbers of bone marrow cells
$15,625 \quad 62,500 \quad 250,000 \quad 1,000,000$ $\begin{array}{llrr}\mathrm{N} T & 11^{*} & 34 & 250\end{array}$ $\begin{array}{lrrr}\text { NT } & 43 & 106 & 412 \\ \text { NT } & 29 & 100 & 400 \\ \text { NT } & 35 & 86 & 436 \\ 15 & 56 & 201 & 792 \\ 18 & 61 & 202 & 860 \\ \text { NT } & 3 & 5 & 51 \\ \text { NT } & 24 & 74 & 167 \\ \text { NT } & 17 & 54 & 216\end{array}$

Experiment I performed using medium containing 10 per cent bovine

Ferum. foetal calf serum.

NT equals not tested.

* Mean number of colonies from two dishes. obtained than with the normal or anaemic marrow cells at all cell dilutions plated. Significantly fewer colonies were obtained with the marrow cells of anaemic mice compared with those from normal marrow cells at the 1,000,000 cell plating level, but the platings at lower cell numbers are not significantly different. No differences were detected in the size, rate of growth or cell morphology of the colonies derived from the three different types of marrow cells used.

The induction of polycythaemia by hypertransfusion rapidly leads to a reduction of the erythropoietic elements in the marrow ${ }^{2}$ while the anaemic state leads to an increase in the number of erythropoietic cells. On this basis the present results suggest strongly that the cell type which is involved in the generation of cell colonies in vitro after stimulation by kidney feeder layer cells is not a member of the erythropoietic cell series and is possibly not a member of the population of stem cells susceptible to commitment by erythropoietin to start differentiation as primitive erythroid cells. This is of special interest in view of the possible production of erythropoietin by the kidney feeder layer cells.

Department of Physiology,

T. R. BradLey

University of Melbourne,

Parkville, Victoria,

Australia.

W. Robinson

D. Metcalf

Cancer Research Unit,

Walter and Eliza Hall Institute,

Melbourne, Australia.

${ }^{1}$ Bradley, T. R., and Metcalf, D., Austral. J. Exp. Biol. Med. Sci., 14, 287 (1966).

${ }^{2}$ Alpen, E. L., Cranmore, D., and Johnston, M. E., in Erythropoiesis (edit. by Jacobson, L. O., and Doyle, M.), 184 (Grune and Stratton, New York, 1962).

\section{RADIOBIOLOGY}

\section{Fall-out Radionuclides in Colorado Deer Liver}

BECAUSE of the numerous and complex functions of the liver, one would expect a wide variety of elements to become concentrated in that organ. According to data compiled by ICRP $^{1}$, at least forty-two stable elements may occur in liver tissues, including caesium, manganese and ruthenium. Radioisotopes of these elements from a variety of sources have been found to accumulate in livers of several species ${ }^{2-4}$. Ingested cerium may also accumulate in the liver ${ }^{5}$ even though absorption from the digestive tract is normally less than $0 \cdot 1$ per cent ${ }^{6}$.

Because deer liver is a choice food item of man, it was of interest to assay samples for fall-out radionuclides. Livers and rumen contents were obtained from wild mule deer (Odocoileus hemionus hemionus) which were collected approximately weekly during the period May 1963-August 1964 from a 580 square mile portion of the Cache la Poudre drainage area in north central Colorado, by the Department of Game, Fish and Parks. Radionuclide assay was performed on bulk samples using $\gamma$-ray spectrometry? ${ }^{2}$ The counting system consisted of a $4 \times 8$ in. $\mathrm{NaI}(\mathrm{Tl})$ crystal connected to a transistorized 400 channel pulse height analyser. The complex $\gamma$ spectra were resolved into components by the technique of matrix inversion using the ' $I B M$ 1620' computer. Peaks were identified by energy and decay rates and compared with spectra produced by standards of known composition and activity. Typical $\gamma$ spectra for rumen and liver samples are given in Fig. 1.

The radionuclide data for liver and rumen contents are summarized in Table 1 . The relatively large sample standard deviations include variation resulting from decreasing levels of activity through time. Because major atmospheric nuclear testing by the U.S.A. and Russia was 